\title{
MENUMBUHKAN KEBIASAAN HIDUP CERMAT DENGAN MEMANFAATKAN CELENGAN DI LINGKUNGAN DESA CIDOKOM KECAMATAN GUNUNG SINDUR
}

\author{
${ }^{1}$ Kharisma Danang Yuangga, ${ }^{2}$ Jasmani, ${ }^{3}$ Irmal, ${ }^{4}$ Dede Supiyan, \\ ${ }^{5}$ Dian Rostikawati \\ ${ }^{1}$ Dosen Fakultas Keguruan Dan Ilmu Pendidikan Universitas Pamulang \\ 2,3,5 Dosen Fakultas Ekonomi Universitas Pamulang \\ ${ }^{4}$ Dosen Fakultas Teknik Universitas Pamulang \\ Email: ${ }^{1}$ dosen00739@unpam.ac.id
}

\begin{abstract}
ABSTRAK
Tujuan dari kegiatan pengabdian kepada masyarakat ini adalah untuk menumbuhkan Kebiasaan Hidup Cermat Dengan Memanfaatkan Celengan Di Lingkungan Desa Cidokom Kecamatan Gunung Sindur.

Metode pengabdian dengan penyuluhan dan sumbang saran serta evaluasi dan ditutup dengan ramah tamah.

Hasil dari kegiatan ini adalah membuka wawasan dari para warga, sehingga tidak hanya memberikan tambahan pengetahuan tetapi juga dapat diterapkan khususnya dalam menerapkan pola hidup hemat, cermat dengan memanfaatkan media celengan. Selain itu diharapkan juga dapat membantu dan meningkatkan pemahaman mereka mengenai financial literacy dalam kehidupan bermasyarakat.
\end{abstract}

\section{Kata Kunci: Hidup Cermat, Menabung}

\section{PENDAHULUAN}

Kecanggihan teknologi sekarang ini kerap menjadi media alternatif para pelaku bisnis untuk memasarkan produknya. Mereka juga tidak kehabisan akal untuk berusaha mendekatkan diri dengan para calon konsumen dengan cara memiliki berbagai akun sosial media yang kini tengah menjadi pusat perhatian di kalangan anak muda, terutama di Indonesia. Hal ini tentu sama-sama mempermudah kedua pihak, baik dari para penjual maupun calon konsumen. Para pemilik produk menjadi lebih mudah untuk menawarkan produknya disertai dengan informasi detail mengenai produk, cara pemesanan, hingga cara pembayaran yang menggunakan metode transfer antar bank. Konsumen menerima informasi dengan cara lebih mudah dan fleksibel karena tidak perlu mengunjungi toko konvensionalnya sehingga dapat menghemat lebih banyak waktu dan biaya.

Kemudahan seperti ini bukan berarti sepenuhnya baik dan sama-sama saling menguntungkan baik produsen atau pemilik produk dengan calon konsumennya.

Dari sisi konsumen, ketidakmampuan untuk mengendalikan diri ketika menginginkan sebuah barang yang sebenarnya bukan sebuah kebutuhan bisa 
mengarahkan seseorang pada belenggu hutang kartu kredit dan tidak mampu memenuhi kebutuhan primer nya sendiri. Celakanya lagi jika para konsumen akhirnya memilih alternatif untuk berhutang kepada keluarga, rekan, bank, atau melalui pinjaman uang online dengan alasan tertentu sehingga mendapatkan 'jawaban sementara' untuk penyelesaian masalah ekonominya. Padahal, alternatif ini nantinya juga akan menimbulkan permasalahan yang sama: hutang yang harus dibayar.

Untuk menghindari kejadian seperti ini, jawaban yang paling tepat adalah dengan menumbuhkan sikap pengendalian diri dan membiasakan hidup cermat. Pengendalian diri ini tidak hanya soal bagaimana mengatur nafsu lapar mata, namun juga mengatur masa depan dengan berbagai kegiatan yang sebetulnya sangat penting dan krusial. Kebiasaan preventif yang harus dibangun sejak dini ini memiliki efek menghindarkan diri dari kebiasaan hutang yang mungkin dimiliki ketika menghadapi masalah keuangan yang mendesak. Unexpected event sangat mungkin terjadi dan resiko ini cukup besar harganya bila tidak memiliki persiapan, misalnya dari segi finansial. Maka, penting untuk memiliki kebiasaan berhemat sebagai salah satu bentuk pengendalian diri. Selain itu kebiasaan berhemat juga memiliki manfaat lain bagi seperti memiliki dana cadangan untuk membangun masa depan karir, modal wirausaha, sebagai dana pensiun, serta tidak perlu bergantung pada asuransi kesehatan.

\section{METODE PELAKSANAAN KEGIATAN}

Adapun metode pelaksanaan program pengabdian masyarakat sebagai berikut:

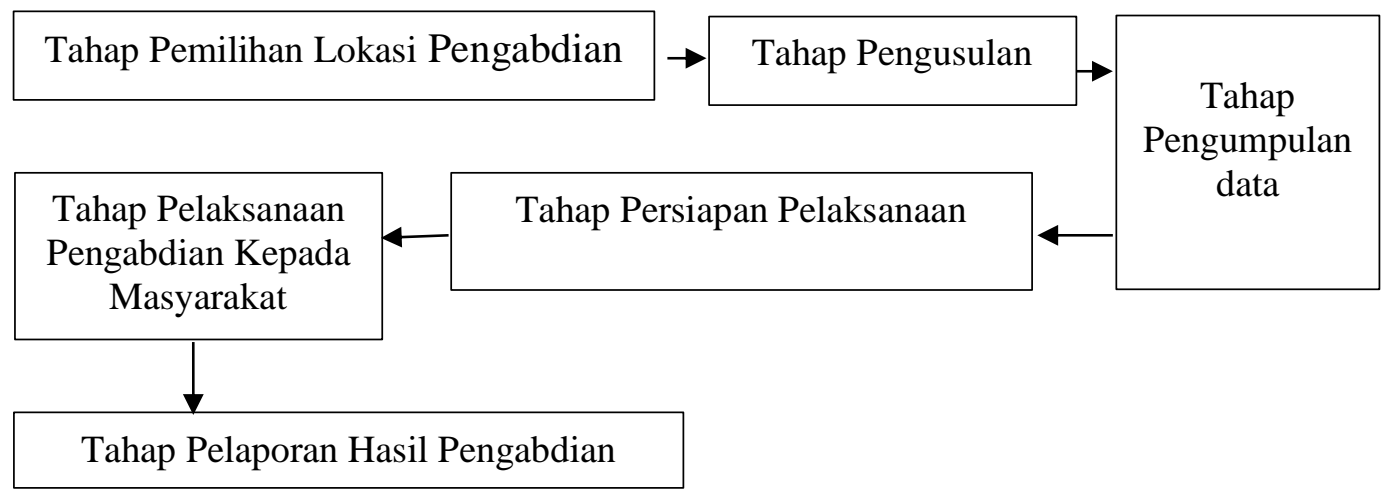

\section{HASIL DAN PEMBAHASAN}

Menghidupkan kembali kebiasaan menabung guna menghindari perilaku hidup konsumtif memang bukan hal yang mudah. Tetapi masyarakat ratusan abad silam sudah mampu melakukan sikap hidup hemat dengan menabung. Bagi masyarakat Jawa, kata Celengan bukan berarti bermain celeng- celeng an atau babi- babi an. Kata celeng dalam masyarakat Jawa lebih merujuk kepada babi hutan. Tapi jika kata celeng diberi tambahan imbuhan --an, menjadi Celengan, maka maknanya menjadi berubah jauh. Th. Pigeaud dalam kamusnya yang 
berjudul Javaans-Nederlands Woordenboek memuat beberapa kata dari bahasa Jawa yang berkaitan dengan aktivitas simpan menyimpan uang alias menabung.

Celengan berarti Spaarpot (tempat menabung), dicelengi berarti opgespaard (disimpan), dan dicelengake berarti men spaart vooriemand (menabungkan untuk orang lain). Dalam Kamus Besar Bahasa Indonesia (KBBI), kata celengan berasal dari kata Jawa yang berarti tabung pekak untuk menyimpan uang; tabungan atau uang simpanan itu sendiri.

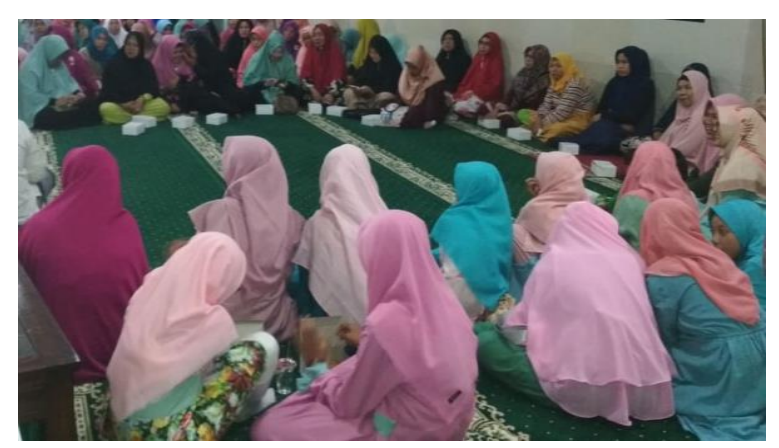

Selain itu, kebiasaan menabung juga mengajarkan untuk berperilaku hidup hemat atau sewajarnya. Bukan menjadi hal baru bahwa masyarakat Indonesia saat ini tengah dilanda wabah gaya hidup hedon dan konsumtif. Membeli beberapa barang atau hal yang sebenarnya tidak perlu atau tidak penting dianggap sebagai hal wajar, apalagi jika hal tersebut sudah berurusan dengan gengsi sosial. akibatnya sudah bisa dilihat di kehidupan nyata. Banyak masyarakat yang terlilit hutang demi memenuhi gaya hidup yang tidak seimbang dengan penghasilannya.

Mengingat pentingnya berhemat dan cermat sebagai salah satu bentuk pengendalian diri ini merupakan bentuk perkembangan sikap yang baik dan akan memberikan keuntungan di kemudian hari, berikut 12 cara untuk hidup cermat dan hemat yang bisa dilakukan.

1. Prioritas: Kebutuhan dan keinginan

Hal ini merupakan salah satu cara yang cukup ampuh dalam menekan pengeluaran. Jadwalkan belanja dengan daftar yang pasti akan digunakan setiap bulannya. Jangan memasukkan barang atau hal-hal yang bersifat keinginan ke dalam daftar prioritas.

2. Pengeluaran $<$ Pendapatan

Usahakan tidak perlu berhutang untuk memenuhi kebutuhan yang setiap waktunya mempengaruhi kelangsungan hidup. Dilihat dari sisi psikologis, kebiasaan berhutang juga tidak baik karena menimbulkan perasaan tidak tenang, selalu cemas, serta gelisah.

3. Menjaga Kesehatan

Pola hidup sehat akan meminimalisir terkena penyakit yang membutuhkan bantuan dokter untuk menanganinya. Jelas ketika menggunakan jasa dokter akan membutuhkan pengeluaran yang jumlahnya relatif tidak sedikit. Hal ini akan berpengaruh pada jumlah pengeluaran yang bisa jadi lebih tinggi daripada pendapatan setiap bulannya. Ketika hal ini menjadi sebuah kebiasaan, pada akhirnya akan selalu merasa kekurangan untuk memenuhi hal-hal yang sifatnya memang sebuah kebutuhan.

4. Bijak Dalam Berbelanja 
Perlu disadari bersama bila lebih menyukai belanja di supermarket yang terkenal bersih dan sejuk, mereka juga menggunakan jasa pemasaran yang selalu bisa mengundang pembeli untuk masuk dan berbelanja di toko mereka dengan teknik-teknik tertentu.

5. Fasilitas Berlibur Murah

Setiap orang pasti membutuhkan rekreasi untuk refreshing dari kepenatan bekerja. Akan tetapi, perhatikan bahwa pengeluaran untuk berlibur tidak perlu mencapai angka fantastis.

6. Membawa Bekal

Kebiasaan satu ini juga akan mengantarkan sebagai pribadi yang memiliki prinsip hidup hemat. Hemat pangkal kaya dan hal ini dimulai dari kebiasaan kecil. Bawalah selalu bekal yang disiapkan dari rumah daripada membeli makanan di luar (yang biasanya dijual dengan harga yang dipatok bisa hingga lima kali lipat). Selain menghemat pengeluaran, membawa bekal dari rumah sudah lebih jelas kebersihan dan gizinya.

7. Membeli barang-barang Investasi

Merasa memiliki uang lebih dan menyadari bahwa tidak cukup 'kuat' untuk membawa banyak dana? Jika memang begitu, bisa mengalihkan dana cair menjadi bentuk barang yang memiliki nilai investasi seperti emas dan tanah. Dua barang ini merupakan contoh barang investasi dengan kemungkinan rugi yang sangat kecil dan jarang mengalami penurunan nilai, apalagi harga tanah. Hal ini bisa membantu untuk memperkecil jumlah dana cair yang siap pakai dan berpotensi bisa langsung dibelanjakan.

8. Go Green

Sikap ramah terhadap lingkungan juga bisa menyelamatkan dari belenggu hutang dan menumbuhkan sikap hemat dalam hidup. Bagaimana caranya? Terapkan dalam kebiasaan hidup sehari-hari seperti menghemat penggunaan listrik (mematikan saklar ketika lampu tidak sedang digunakan), menghemat penggunaan

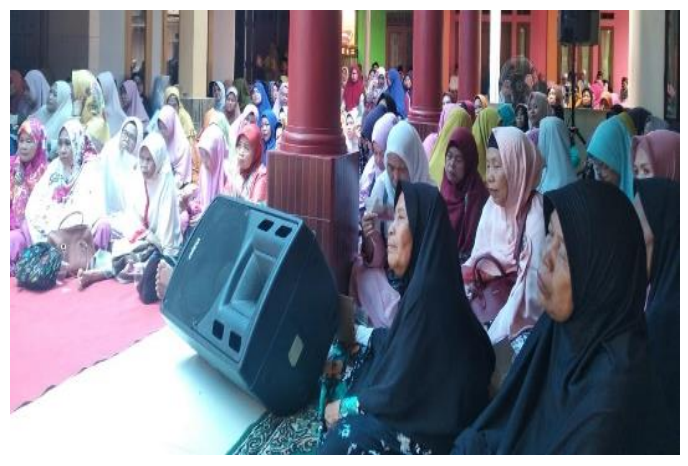
air, menggunakan kendaraan sepeda untuk menjangkau tujuan yang berjarak kurang dari 5kilometer dari rumah. Sikap-sikap yang turut membantu pelestarian bumi ini juga turut membantu merealisasikan sikap hidup hemat.

9. Jangan Meremehkan Uang Receh

Besar nominal yang dimiliki memang terkesan kecil tetapi tidak pernah tahu bahwa kumpulan uang receh ini bisa menjadi besar nominalnya dan mungkin menyelamatkan di saat-saat terdesak.

10. Menerapkan Pola Hidup Sederhana

Meski Anda berpenghasilan 10 juta ke atas setiap bulannya, hal itu tak akan menjamin untuk selalu menjadi orang kaya. Orang yang dianggap kaya 
bisa menjadi kaya karena ketekunannya dalam mengumpulkan pundi-pundi rupiah lewat kerja keras mereka dan sangat menjaga pendapatan mereka dengan selektif dalam membuat pengeluaran.

11. Disiplin Dalam Menabung

Kebiasaan disiplin dalam menabung merupakan sikap yang bersifat wajib dalam mewujudkan pola hidup hemat.

\section{KESIMPULAN DAN SARAN}

Dengan ada kegiatan ini menjadikan para warga di lingkungan Desa Cidokom Kecamatan Gunung Sindur dapat memahami pentingnya pola hidup hemat, cermat dan berpikir progresif dengan memanfaatkan media celengan.

Selama kegiatan berlangsung peserta penyuluhan memberikan tanggapan yang sangat baik, hal ini dapat dilihat dari dukungan dan atusiasme mereka dalam setiap kegiatan yang diadakan, dengan pengabdian ini dapat membuka wawasan dari para warga, sehingga tidak hanya memberikan tambahan pengetahuan tetapi juga dapat diterapkan khususnya dalam menerapkan pola hidup hemat, cermat dengan memanfaatkan media celengan. Selain itu diharapkan juga dapat membantu dan meningkatkan pemahaman mereka mengenai financial literacy dalam kehidupan bermasyarakat.

\section{DAFTAR PUSTAKA}

Kamus Besar Bahasa Indonesia (KBBI)

Handoko, Hani. 2012. Manajemen Personalia dan Sumber Daya Manusia Edisi 2. BPFE Yogyakarta.

Yuangga, K. D., Asmalah, L., \& Sudarso, A. P. (2019). PENYULUHAN MERAIH PRESTASI DENGAN JUJUR DAN PERKUAT INTEGRITAS. Jurnal Pengabdian Dharma Laksana, 2(1), 36-41. 


\section{PANDUAN SINGKAT BAGI PENULIS JURNAL DHARMA LAKSANA}

Panduan penulisan ini dimaksudkan untuk menyeragamkan bentuk penulisan karya ilmiah yang dikirim penulis ke redaksi Jurnal Jenius, dengan panduan penulisan sebagai berikut :

1. Naskah ditulis dalam Bahasa Indonesia dengan Abstrak Bahasa Indonesia atau Bahasa Inggris dalam bentuk Font 12" dengan ukuran 1 Spasi dengan intisari tidak lebih dari 250 kata disertai 3 atau 4 kata kunci (keyword).

Naskah berupa Softcopy program MS maksimal 10 Halaman termasuk tabel dan gambar, spasi 1.

2. Sistematika penulisan disusun dengan urutan sebagai berikut :

a) Judul, nama dan alamat email penulis/peneliti tunggal.

b) Abstrak dan intisari, keyword dan kata kunci.

c) Batang Tubuh :

1). Pendahuluan, termasuk didalamnya intisari permasalahan

2). Metode Penelitian

3). Hasil dan Pembahasan

4). Kesimpulan dan Saran

5) Daftar Pustaka atau Referensi

6) Seluruh isi tersebut di buat dengan 1 kolom

3. Judul ditulis dalam bentuk font Times New Roman 12" dengan huruf besar kecil dicetak tebal dan ditempatkan ditengah halaman,, serta tidak lebih dari 18 kata.

4. Tulisan karya ilmiah dalam bentuk font Times New Roman 12" dengan ukuran spasi 1,0 spasi dalam bentuk kolom.

5. Gambar diberi nomor dan keterangan, sedangkan tabel diberi nomor dan keterangan diatasnya.

6. Penulisan persamaan matematika yang terdapat pada halaman naskah hendaknya menggunakan equation editor.

7. Daftar pustaka hanya memuat literature yang dirujuk dalam keterangan dan dicantumkan pada bagian akhir naskah dilakukan dengan memberikan nomor.

8. Margin atas dan kiri $4 \mathrm{~cm}$, kanan dan bawah $3 \mathrm{~cm}$, dan ukuran kertas A4.

9. Dokumentasi Foto kegiatan maksimal 5.

10. Email Redaksi :.jpdl@ unpam.ac.id / denoksunarsi@unpam.ac.id. 